\title{
Challenging Students' Critical Thinking Skills: Integrating Socio-critical and Problem-oriented Approach in Nanoscience and Nanotechnology Learning
}

\author{
Yuli Rahmawati", Risky Amalia, Setia Budi \\ Faculty of Mathematics and Natural Sciences, Universitas Negeri Jakarta, Indonesia \\ Received October 3, 2019; Revised November 30, 2019; Accepted December 4, 2019
}

Copyright $\bigcirc 2020$ by authors, all rights reserved. Authors agree that this article remains permanently open access under the terms of the Creative Commons Attribution License 4.0 International License

\begin{abstract}
The aim of this study was to develop undergraduate students' critical thinking skills using a socio-critical and problem-oriented approach to the study of nanoscience and nanotechnology (NST) materials. This study discusses the social scientific issues regarding NST that occur in society. The research was conducted with 33 participants using a qualitative research approach where interviews, observations, reflective journals, and critical thinking questions were employed as data collection. The results show students' critical thinking skills developed where they were able to identify issues, explain issues with scientific concepts, connect ideas or concepts, provide good arguments and provide conclusions based on some evidence. The students faced the challenges in developing their critical thinking skills in relation to chemistry concepts.
\end{abstract}

Keywords Socio Critical and Problem Oriented, Nanoscience and Nanotechnology, Critical Thinking Skills

\section{Introduction}

Critical thinking and the ability to solve problems are essential competences for technological and scientific advancements in the 21 st century $[1,2]$. Education aims to improve student's understanding as well as produce young people who have the ability to be agents of change [3]. Education should be able to prepare students to have skills that will be useful in the future. The demand of people mindset in the 21 st century is to create education that can produce human resources [4] which are expected to build social and economic order. Students need to be able to think critically, creatively, and innovatively, and have good communication and collaboration skills [2]. UNESCO has declared that education should be directed to: 1)
Interdisciplinary and holistic learning rather than subject-based learning; 2) values and critical thinking rather than rote learning, and 3) decision-making skills [5]. The younger generations are faced with conditions where they must have sufficient critical thinking skills to be able to solve problems [6]. In this research context, critical thinking refers to the ability to think, analyze, synthesize, and identify and solve problems effectively [7-9]. According to [10], critical thinking is reasoning and reflective thinking by making decisions based on their belief. According to Facione (2006), the most basic concepts of critical thinking are the ability to interpret, analyse, evaluate, infer, explain and self-regulate [7]. While critical thinking skills, according to Onosko \& Newmann (1994) challenge students to interpret, analyze or manipulate information [11].

Based on research studies by [12] that found that $40 \%$ of students cannot explain their answers with critical reasons, and study showed only $40 \%$ of students who can think critically while the learning process [13], students' critical thinking skills need to be continuously improved. According to [14], students in Indonesia have low levels of critical thinking skills as revealed by research that the critical thinking skills of prospective teachers reached just $36.26 \%$ for those with a science background, $26.62 \%$ from a non-science backgrounds, and 34,06\% for all student teachers. Chemistry education students find knowledge related to everyday life was difficult; therefore it is felt by student that critical thinking skills need to be improved. It is relevant that, a view consistent with findings from [15] that chemistry learning is less attractive to students because of a disconnect between concepts and chemical applications in their daily lives. In the current learning process, students are not connected with problems that occur in the community, they are not able to apply several concepts or ideas to studying a problem and they are not effectively involved in providing supporting arguments. 
Learning should involve student argument and critical thinking [16-18].

In the study of nanoscience and nanotechnology, critical thinking skills are required for students to be able to understand nanoscale characterization and measurement, and for preparing students in the development and risk management of nanoscience and nanotechnology applications in everyday life [19]. Knowledge of nanoscience and nanotechnology and its integration with overall daily life is important for science students given that it is estimated that the industrial use of nanomaterials will continue to increase in the future [20]. Critical thinking skills will improve students' understanding of chemical concepts as they will be encouraged to carry out various activities such as facing challenges in learning, discovering new things, and solving problems [6]. In order to achieve good quality solutions to problems students need to understand the problem, make a problem-solving plan, and think critically to consider alternative solutions that are more practical [6]. Therefore, meaningful nanoscience education is needed so that innovative, critical and creative ideas can be used to solve problems in everyday life [6].

Unlike other fields of science education, there are several gaps in teaching important ideas from nanoscience and nanotechnology [21]. Learning nanoscience and nanotechnology is a multidisciplinary approach [22] that is rapidly developing in various fields, especially in economics and sociology [23], which means that nanoscience and nanotechnology issues are very closely related to everyday life. One of the goals of nanoscience and nanotechnology education is to encourage students to provide possible arguments when making decisions about social issues related to nanoscience and to enable students to discuss the benefits and risks that affect health and the environment [24]. A socio-critical and problem-oriented approach can be used to provide the kind of learning in nanoscience and nanotechnology as advised by the research.

A socio-critical and problem-oriented learning approach is one way of linking the nanoscience and nanotechnology concepts learned in class with social problems that occur in society. Socio-critical and problem-oriented learning provides the environment where controversial social issues can be discussed in a way where students feel free to openly express opinions and make decisions [25]. Socio-critical and problem-oriented chemistry learning can stimulate critical and creative thinking and argumentation
$[3,26]$. According to Christenson, Rundgren, \& Zeidler (2014), a combination of science concepts and social-scientific problems is an effective way to involve students in active discussion and develop their ability to think critically and make decisions [27]. In addition, it helps students build chemistry concepts holistically [28].

This study aims to analyze students' critical thinking skills in the application of socio-critical and problem-oriented learning in the study of nanoscience and nanotechnology materials. In the learning process, students examined the pros and cons of social scientific issues and problems that occur in the community relating to the application of nanoscience and nanotechnology. Each group presented a poster representing their views on the issues raised that were then debated in front of the class.

\section{Materials and Methods}

This study analyzed students' critical thinking skills in the application of socio-critical and problem-oriented approach to the study of nanoscience and nanotechnology materials. The research was conducted with 33 chemistry student participants at a university in Indonesia. The socio-critical and problem-oriented approach was undertaken in 3 stages: understanding concepts, socio-ecological studies and debating [29], as shown in the Figure 1 below.

During the first stage, the lecturer provided an understanding of nanoscience and nanotechnology concepts and divided the class into groups. Each group was given articles containing social scientific issues that occurred in the community related to nanoscience and nanotechnology. These issues included the use of Nano-sunscreens, Nano silver in textiles, Nano in food packaging, and Nano drug delivery. Each issue was discussed by two groups from opposing perspectives, namely the pros and cons. In the second stage, students looked for sources of information relating to the social scientific issues provided and discussed them as a group. A poster of the various views was created and used to support a class debate on the issues raised. An analysis of students' critical thinking skills was carried out during the learning process. Interviews, reflective journal writing, assessment of observations and critical thinking test questions according to the critical thinking skills rubric of SCIT1020, 2013 were used to gather data for the study.
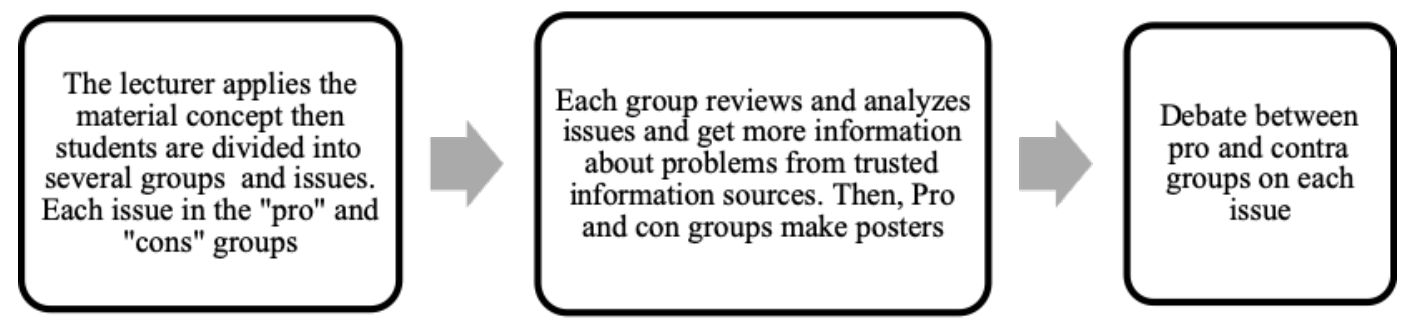

Figure 1. Stages of Socio-critical and Problem Oriented Learning Process 


\section{Results and Discussion}

This research provided opportunities for students to critique social issues and problems that occur in the community. Issues were identified in articles and were discussed in groups. Group discussions provided opportunities for students to communicate $[30,31]$ and allowed individuals to develop more comprehensive solutions [30]. Group learning can optimize social interaction with teachers and with other students. It can facilitate communicating scientifically, foster teamwork, build a sense of responsibility, help solve problems, and increase understanding of concepts [32]. Each issue or problem was presented and evaluated from two different perspectives in order to encourage students to think critically and to communicate clearly.

\subsection{Learning with Social Scientific Issues}

The learning of nanoscience and nanotechnology based on a socio-critical and problem-oriented approach can connect scientific concepts with problems or issues in the community [33]. The issues raised in this study relate to the application of nanoscience and nanotechnology in everyday life. The study provided students with an opportunity to think critically and discuss their thoughts during the learning process, and by debating the issues from different perspectives. Learning should no longer just strengthen concepts but also provide opportunities to learn how to involve argumentation and critical thinking in learning and use those concepts to solve problems in daily life $[34,35]$. Debates about issues that affect the community can increase students' enthusiasm and motivation to learn, as can be seen from students' responses below:

\section{Reflective Journal, Student 29, November 22, 2018}

"I feel very excited and interested in the issues raised, and I am enthusiastic in dealing with every question posed and answering it by using experience, the concept of nanoscience obtained as well as information about issues raised from journals"

\section{Reflective Journal, Student 29, December 6, 2018}

"This learning is very interesting and right to be used to increase student activity, can hone thinking and add insight, learning with social scientific issues make learning process more active and make me to think a lot of the issues."

In preparing for the debate, students felt that learning became more meaningful when they were able to discuss the issues and connect them to nanoscience concepts. The learning process encouraged students to collaborate and to develop arguments using critical thinking skills as indicated by the response below:

"This learning provides benefits because it builds conceptual and contextual knowledge because before giving an argument, we explored thoughts from existing sources so that we had valid and concrete arguments to be able to think critically and build high-level thinking." (Student Interview 18, December 18, 2018)

The socio-critical and problem-oriented learning approach used in this study aimed to increase student motivation and attitude towards chemistry, and to achieve other educational goals as espoused by Marks \& Eilks (2009), such as building critical thinking skills, communicating opinions and solving problems so that students build their readiness for life in a modern, science and technology based society [25]. Mintzes and Lin (2010), state that students will be more motivated to actively express opinions in discussions about controversial topics through their experiences in chemistry learning [5]. Christenson et al., (2014) concur that a combination of chemical concepts and social-scientific problems is an effective way to involve students in discussions and develop their ability to make decisions and think critically [27].

\subsection{Student's Critical Thinking Ability in the Learning Process}

The impact of socio-critical and problem-oriented learning on students' critical thinking skills was observed during the learning process while discussing social scientific issues from different perspectives and taken from the results of critical thinking tests, validated by 5 expert lecturers in education, materials, chemistry and nanoscience and nanotechnology. Critical thinking indicators included identification of questions on given issues, conceptual understanding and connection of ideas, making assumptions, and drawing conclusions [36]. The following is a description of each critical thinking indicator:

\subsection{Issue Clarification}

In the learning process, social issues were debated, thereby encouraging students to increase their curiosity regarding the issues under study. This can be seen from a participant's response regarding the learning process:

"Such learning methods can make me want to know more about the issues raised. When I brought the issue in front of the class, I looked for various reference sources so that the information I submitted was valid, However, when I was in the audience, I was interested in asking various questions of the debating team regarding the issue being discussed."

(Student interview 30, December 6, 2018)

Students were motivated to ask questions when issues were discussed from opposing sides. This approach aligns with the socio-critical and problem oriented learning objectives proposed by Feierabend \& Eilks (2011). The questions raised by students were useful in clarifying their 
understanding of the issues. The results showed that the average student could identify questions about confusing topics, as seen from the questions below that were raised by students during the debate:

Student 30: I want to ask for the pro group, where are the Nano sensors chips in food? And how can the sensor chip be prevented from being damaged?

Pro Group: Based on the journal that I have read, the Nano sensor for detecting decay is attached to food wrapping paper, so there is a sensor side facing the food and some come out of the packaging. Then, the sensor chip has a long use time because it can be used several times to detect decay in fish. The use of the sensor chip does not reach the consumer only the manufacturer, so the producer can use it again for packaging the other fish.

The questions raised were important because the other participants could add information according to the questions and answers given.

\subsection{Conceptual Understanding}

In socio-critical and problem-oriented learning, students integrate an understanding of the concepts of nanoscience and nanotechnology with applications to everyday life that are often controversial. At the beginning of the project, students were given information about nanoscience and nanotechnology and were expected to be able to connect the concepts to the issues under study. Students then discussed the social scientific issues in depth with their group and prepared for a debate using reliable sources such as journals and books. Students were compelled to find more information and increase their initial knowledge related to the issue. The results of the study showed that the average conceptual understanding of students was developed from previous learning using the direct teaching approach, meaning that students could provide ambiguous responses and the content used had improved. The following is a sample from a student's critical thinking test:

"The use of nanomaterials can improve performance due to the small particle size. Size can affect the characteristics of a particle because when a particle gets smaller the prevailing laws of physics will be dominated by the laws of quantum physics which will affect the physical properties of particles such as optical, electrical, magnetic and conductivity. The smaller the particle size, the more particles are exposed to the surface, which will increase the reactivity of the large particles because the collisions between particles increase so that the reaction runs faster, therefore the nanoparticles are a good catalyst"

(Student 13, 10 January 2019)

From the tests results above, students can respond to the problems using an appropriate and adequate understanding of the content. The student's statement is in accordance with the concept of nanoscience.

\subsection{Relevance between Ideas}

The results in this study show that in the application of a socio-critical and problem-oriented approach, students' ability to integrate various ideas such as social aspects, scientific concepts, health and the concepts of nanoscience and nanotechnology when discussing issues. Additionally, students felt more confident in expressing opinions or ideas that their colleagues could understand. The debate transcript below shows students were able to connect several ideas when discussing an issue or problem:

Pro: Today many diseases are caused due to bacterial and microbial activity, so the use of antibacterial substances in clothing is very necessary. One of them is the use of Nano silver in clothing as an antibacterial agent that is more effective and has been proven to be safe and less toxic than other antibacterial substances.

Cons: The use of Nano silver in clothing is still being investigated further on health aspects; in vivo studies show that using Nano silver for 14 days with low concentrations in male mice can increase the hormone testosterone. This increase in hormones can cause insomnia, depression and reduced self-confidence. Nano silver exposure through inhalation can cause death, and long-term use of Nano silver can cause argyria disease (grayish skin).

Pro: The use of Nano silver in textiles has proven safe and low risk, because the use of Nano silver in clothing instead of through oral or directly into the body. Nano silver in clothing will bind to the -SH group on bacteria which causes bacterial cell membranes to break and die. Cons: However, the use of Nano silver will also have an impact on the ecosystem in the environment due to the release of Nano silver from clothing to waste that will go into the environment. One risk is to inhibit phytoplankton photosynthesis

The transcript above shows that participants were able to identify a relationship between ideas when discussing the social scientific issues given. Students could identify health problems, the side effects of Nano silver use, how Nano silver works to kill bacteria and the effectiveness of nanoparticles as antibacterial substances. The explanation that Nano silver kills bacteria is in accordance with Holt and Bard's (2005) explanation that, silver ions cause respiration inhibition, membrane damage and destruction of proton motive power [37, 38].

\subsection{Argumentation}

The debate process, used to address social issues, encouraged participants to actively express their opinions or assumptions in accordance with the views of each group. Issues raised by each group were first reviewed 
through discussion where various assumptions or opinions relevant to the debates were gathered. These assumptions, based on valid data from a variety of trusted sources, enable participants to convince the audience that the group's opinion was correct. The results of the study show that an average student can make relevant assumptions about the issues, as demonstrated below:

"In my opinion, as consumers, using Nano sunscreen we must be more careful and seek knowledge about recommended use, or use safer sunscreen products, for example: propolis (nanoparticles) containing folifeol and flavonoids which can function as antioxidants, anti-inflammatory and protector against UV light; eating food contains antioxidants like strawberry and green tea"

\section{(Test Results for Students 11, 10 January 2019)}

Participants were challenged to develop their critical questions through curiosity in a case. Curiosity can stimulate students' critical questions [39]. The participant's response was in accordance with the theory that phenolic compounds such as flavonoids are one of the powerful antioxidants that can prevent the danger of UV light. These flavonoids can be extracted from flower roselle [40]. These assumptions, identified by the participant, are important insights.

\subsection{Presenting Conclusions}

During the learning process participants were observed drawing conclusions based on the results of discussions and debates. The results of the study show that an average student be able to provide conclusions with some evidence, as follows:

"The conclusion that I can give, Nano silver Ag can be a solution in the textile industry because it is more effective as an antibacterial but the use and waste of silver nanoparticles must be handled properly so that their use becomes effective and does not damage the environment. An example of the response being tested by Ciba is the handling of laundry wastewater containing $\mathrm{Ag}$ nanoparticles inserted into the resin column to remove Ag ions so as not to pollute the environment"

(Participant 11, 10 January 2019)

The participant's conclusion is correct based on the data and consistent with the group's views on the issues raised. According to Dastjerdi \& Montazer (2010), silver nanoparticles are non-toxic and intolerant disinfectants. Using silver nanoparticles causes an increase in surface area thus, the anti-bacterial effect can be maximized [41].

Based on the description above, it can be seen that a student's critical thinking ability can be developed through socio-critical and problem-oriented learning in response to issues that occur in the community. The critical thinking ability demonstrated by this participant, among others, indicates that students are able to identify important questions from ambiguous topics, explain issues in sufficient detail, connect some ideas or concepts effectively, provide a relevant argument and conclusions with supporting evidence.

\section{Conclusions}

The application of socio-critical and problem-oriented learning increased students' interest in learning the concepts and applications of nanoscience and nanotechnology whilst also encourage them to cooperate in discussions and actively express their opinions or ideas. Learning by discussing social scientific issues that occur in the community encourages students to be more sensitive to environmental problems related to the use of nanotechnology products. They are more likely to find out about issues through reliable sources that can provide valid and logical information. Observations supported one of the aims of the project to improve students' critical thinking skills during the learning process. Analysis showed that through socio-critical and problem-oriented learning the average critical thinking ability of students developed in response to issues that occur in the community. In this study, the participant's critical thinking was demonstrated by their ability to identify important questions from topics with some confusion, were able to explain issues with sufficient content, connect some ideas or concepts quite well, and provide good arguments and conclusions with some evidence.

\section{REFERENCES}

[1] Chinchilla Calvo C, Silmi Moyano A, Rabadan Marina M. Skills matter. Epub ahead of print 2016. DOI: 10.1787/9789264258051-en.

[2] P21: Partnership for 21st Century Learning. Framework for 21st Century Learning - P21. P21.org, http://www.p21.org/ our-work/p21-framework\%0Ahttp://www.p21.org/about-u s/p21-framework (2007).

[3] Ridwan A, Rahmawati Y, Nurbaity, et al. Integration of a Socio-critical and Problem Oriented Approach In Chemistry Learning for students' Soft Skills Development. MIER J Educ Stud Trends Pract 2017; 7 No. 1: 33-41.

[4] Santika AR, E N, W P. Analysis of students' critical thinking skills in socio- scientific issues of biodiversity subject. J Phys Conf Ser. Epub ahead of print 2018. DOI: 10.1088/1742-6596/1013/1/012004.

[5] Mintzes JJ, Lin. Learning argumentation skills through instruction in socioscientific issues: the effect of ability level. 2010; 993-1017.

[6] Zetriuslita, Ariawan R, Nufus H. Students' critical thinking ability: Description based on academic level and gender. J Educ Pract 2016; 7: 154-164. 
[7] Facione P a. Critical Thinking: What It Is and Why It Counts. Epub ahead of print 2006. DOI: ISBN 13: 978-1-891557-0 7-1.

[8] Lai ER. Critical thinking: A literature review research report. Canada, 2012.

[9] Angelo TA. Beginning the dialogue: Thoughts on promoting critical thinking: Classroom assessment for critical thinking. Teach Psychol 1995; 22: 6-7.

[10] Ennis R. A Concept of Critical Thinking. Harvard Educ Rev 1962; 32: 81-111.

[11] Onosko JJ, Newmann FM. Creating more thoughtful learning environments. Creating powerful thinking in teachers and students diverse perspectives. 1994; 27-49.

[12] Arum R, Roksa J. Academically adrift: Limited learning on college campuses. New York: Springer-Verlag, 2011. Epub ahead of print 2011. DOI: https://doi.org/10.1007/s12115011-9417-8.

[13] Aktamiş H, Yenice N. Determination of the science process skills and critical thinking skill levels. Procedia - Soc Behav Sci 2010; 2: 3282-3288.

[14] Mayadiana D. Pembelajaran dengan Pendekatan Diskursif untuk Mengembangkan Kemampuan Berpikir Kritis Mahasiswa Calon Guru SD. UPI Bandung :Tidak Diterbitkan, 2005.

[15] Marks R, Stuckey M, Belova N, et al. The societal dimension in German science education - from tradition towards selected cases and recent developments. Eurasia J Math Sci Technol Educ 2014; 10: 285-296.

[16] Daniel G. Kecerdasan Emosi untuk Mencapai Puncak Prestasi. terj. Alex Tri Kantjono. Jakarta: PT. Gramedia Pustaka Utama, 2003.

[17] Daniel G. Emotional Intelligence. 10th Anniv. New York: Bantam, 2005.

[18] Dewiyani MJ. Improving Students Soft Skills using Thinking Process Profile Based on Personality Types. Int J Eval Res Educ J 2015; 4: 2252-8822.

[19] Asrorudin U. PENGEMBANGAN SENSOR GAS BERBASIS TIMAH OKSIDA (Sn02). Akademi Kimia Analisis, 2009.

[20] Sebastian V, Gimenez M. Teaching Nanoscience and Thinking Nano at the Macroscale: Nanocapsules of Wisdom. Procedia - Soc Behav Sci 2016; 228: 489-495.

[21] Blonder R, Sakhnini S. Teaching two basic nanotechnology concepts in secondary school by using a variety of teaching methods. Chem Educ Res Pract 2012; 13: 500-516.

[22] Christine O, Hayden H. Contextualising nanotechnology in chemistry education. Chem Educ Res Pract 2008; 9: 43-50.

[23] Laherto A. Incorporating nanoscale science and technology into secondary school curriculum: Views of nano-trained science teachers. Nord Stud Sci Educ 2011; 7: 126.

[24] Moor J, Weckert J. Nanoethics: Assessing the nanoscale from an ethical point of view. Discov Nanoscale 2004; $301-$ 310 .

[25] Feierabend T, Eilks I. Teaching the societal dimension of chemistry using a socio-critical and problem-oriented lesson plan based on bioethanol usage. J Chem Educ 2011; 88: $1250-1256$.

[26] Amalia R, Rahmawati Y, Budi S. Pengembangan Keterampilan Argumentasi Calon Guru Kimia Melalui Pendekatan Socio Critical and Problem Oriented. J Tadris Kim 2019; 1: 91-104.

[27] Christenson N, Zeidler. The Relationship of Discipline Background to Upper Secondary Students' Argumentation on Socioscientific Issues. Res Sci Educ 2014; 44: 581-601.

[28] Zeidler DL, Sadler TD, Simmons ML, et al. Beyond STS: A research-based framework for socioscientific issues education. Sci Educ 2005; 89: 357-377.

[29] Eilks I. Teaching 'Biodiesel': a Sociocritical and Problemoriented Approach To Chemistry Teaching and Students' First Views on It. Chem Educ Res Pr 2002; 3: 77 85 .

[30] Scanniello G, Erra U. Distributed modeling of use case diagrams with a method based on think-pair-square: Results from two controlled experiments. J Vis Lang Comput 2014; 25: 494-517.

[31] Damian D, Lanubile F, Mallardo T. On the need for mixed media in distributed requirements negotiations. IEEE Trans Softw Eng 2008; 34: 116-132.

[32] Ibrahim AR. Upaya Meningkatkan Hasil Belajar Mahasiswa melalui Penerapan Model Pembelajaran Think Pair and Share pada Mata Kuliah Kimia Dasar 1. 2010; 13: 77-81.

[33] Marks R, Eilks I. Promoting scientific literacy using a sociocritical and problem-oriented approach to chemistry teaching: Concept, examples, experiences. Int J Environ Sci Educ 2009; 4: 231-245.

[34] Mulyasa E. Kurikulum Tingkat Satuan Pendidikan, Sebuah Panduan Praktis. PT. Remaja Rosdakarya, 2007. Epub ahead of print 2007. DOI: https://doi.org/10.1007/s00393018-0552-0.

[35] Putardi S. Pendidikan Berorientasi Lingkungan: Pergeseran Peran Bahan Alam Sebagai Media Pembelajaran Kimia, http://ejournal.pkpsmikipmataram.org/index.php/hydrogen /article/viewFile/395/371 (2006).

[36] SCIT1020. Rubric for Critical Thinking Skills. Power Sci Technol.

[37] Holt KB, Bard AJ. Interaction of silver(I) ions with the respiratory chain of Escherichia coli: An electrochemical and scanning electrochemical microscopy study of the antimicrobial mechanism of micromolar Ag. Biochemistry 2005; 44: 13214-13223.

[38] Hobman JL, Crossman LC. Bacterial Antimicrobial Meteal Ion Resistance. Med Microbiol 2015; 64: 471-497.

[39] Rahmawati Y, Khoul. Fieldwork, co-teaching and co-generative dialogue in lower secondary school environmental science. Issues Educ Res 2016; 26: 147-164.

[40] Marpaung ME, Luliana S, Ressi S. Uji Aktivitgas Krim Ekstrak Metanol Bunga Rosella (Hibiscus sabdariffa) Sebagai Tabir Surya. Universitas Tanjungpura, 2015.

[41] Dastjerdi R, Montazer M. A review on the application of 

in Nanoscience and Nanotechnology Learning

inorganic nano-structured materials in the modification of textiles: Focus on anti-microbial properties. Colloids Surfaces B Biointerfaces 2010; 79: 5-18. 